\title{
The psychological imagination ${ }^{1}$
}

\author{
Luca Tateo* \\ Aalborg University, Center for Cultural Psychology. Aalborg, Denmark
}

\begin{abstract}
The commentary presents an epistemological reflection about Dialogical Self theory. First, the theoretical issues of DS about the relationship between individuality, alterity and society are discussed, elaborating on the articles of this special issue. Then, it is presented the argument of psychologist's ontological fallacy, that is the attitude to moving from the study of processes to the study of psychological entities. Finally a development toward new research directions is proposed, focusing on the study of higher psychological functions and processes, taking into account complex symbolic products of human activity and developing psychological imagination.
\end{abstract}

Keywords: higher psychological functions, psychologist's ontological fallacy, dialogical self, psychological imagination.

\section{Microcosms and macrocosms}

Dialogical Self theory (Hermans, 2001) is one of the most successful approaches of the last decade in the study of Self. Its prompt diffusion it is probably due to its characteristic of being a long-range theory, able to account for several aspects of "normal" and "pathological" psychological phenomena. The strong theoretical assumption of is the conception of the mind as a microcosm of the society, a dynamic multiplicity of relatively autonomous positions in dialogue (Hermans, 2014). Positions evolve through an internalization of significant others' and culture's voices, that become the cast or repertoire of an inner drama, what could be called the novel of our life. In some recent advancements of the theory, Hermans (2014) is trying to explicitly link the microcosm of Self's arena with the macrocosm of society. This link is operated by defining three different levels of positioning: the internal domain of the self, made of internalized voices; the external domain, of the Self, in which significant others are positioned, forming the "society of Self" (Hermans, 2014); and the societal domain in which real individual, institutions and cultures dialogue with the Self. This could be considered a wise theoretical move to include a more ecological model of Self in society, in which the dynamics of positioning (e.g. collations, asymmetries, power relationships, alliance, etc.) can echo the wider societal dynamics, accounting for the role of cultures and sub-cultures in the formation and elaboration of the Self system. It is a very intriguing development, since only Freud's theory, in my humble opinion, probably provided such a global account for the relationship between profound dynamics of the psychological life and the

1 This work has been funded by the Marie Curie IEF-2012 grant "EPICS. Epistemology in psychological science, the heritage of Giambattista Vico and the cultural psychology" at Aalborg University (Denmark).

* Corresponding address: luca@hum.aau.dk societal forces that in actual fact shape individual experiences and life trajectories.

In many of the articles of this special issue, I can read a specific attention to the relationship between the development of the Self system and the societal challenges at large. That is why I would like to point at some potential research directions and topics that could revive the concept of Dialogical Self.

The new developments of Dialogical Self Theory try explicitly to grasp the implications of the identity-alterity problem in present times when multiplication and globalization of subjects is posing new questions. I would say that the Hearth's overpopulating and multiplication of migration flows is jeopardizing the microcosm with respect to a potential overpopulation of the society of Self system. In this context, the issues of development and education become central. Indeed, we still know little about the way the internal domain of self develops in specific periods of life, e.g. the period from infancy to adolescence, with respect to the evident presence of the external domain, the adults, in relation to the larger societal challenges of the alterity in a globalized world.

For instance, Simão and Sánchez, in this special issue, focus on the relationship between identity and alterity in infancy through an empirical study on the community of Colombian Indigenous people Nonam. In this article, the dialogical space is conceptualized as ego-alter-world relationship (Simão, 2012). The study shows the importance of not focusing just on the lowest level of symbolic analysis (no matter if more or less quantitative or interpretative study of linguistic utterances) but on complex products of human activity such as myths and social practices. In this case, the process of elaboration of the Self system during infancy is studied in the context of the activity of myth narratives that takes place between mothers and children of the Indigenous community. This is a very important point to stress, if the object of psychological science is the dynamic relationship between the ego, the alterity and the societal context, then, as the Danish psychologist and philosopher Harald Höffding (1905) elegantly expressed more than one century ago: 
If we want to find out the elements and laws of mental life it is not enough to study the single individual in its special states. A study is also required of human works and ideals, in which the nature of mental life is revealed throughout the ages. There exists no mental life in general. It appears in different forms at different times and places, and it strives to develop itself as fully as possible in every one of these forms, though the totality of its elements has a different timbre in every special case. (Höffding, p. 76)

Simão and Sánchez also stress a hot spot of psychological epistemology. One cannot abstract from the concrete situation in which people and researcher interaction in the context of the research. It often treated as a suspended state in which the dialogical dynamics of the encounter with alterity are simply neglected (by the researcher). The research is nothing but a special case of the dialogical space in which all the participants play their drama (Tateo $\&$ Marsico, 2014). Thus, Simão and Sánchez remind us to adopt the same systemic gaze, considering the relationship between the researcher and the participants as developing process that implies the qualitative change of both the subject and the object of knowledge.

The form of alterity par excellence that a person can experience in his own life is the divinity, which is another context of the human activity in which the micro and the micro, the inner and the outer which can be an interesting field of application for Dialogical Self theory (Valsiner, 2007).

In Religion men have made some of their deepest and most intensive mental experiences. If religion is genuine and original, all the elements of mental life are at work in it with an energy and interplay not to be found in any other domain. The study of religious life is therefore of great importance to general psychology. (Höffding, 1905, p. 77)

In religious experience, which is such a relevant part of everyday life for a large part of the population in countries like Brazil, the Self system is dealing with extremely hyper-generalized I-positions, including the divinity and the community of believers. The person develops what Hermans (2014) calls meta-positions that play the function of managing the unity of the society of self in presence of very demanding, sometimes controversial and valued voices. The relationship between the internal, external and societal domains is particularly interesting in religious experience because people must keep together a sense of external force, the divinity, with the need of maintaining a high personal integrity and at the same time answering the many questions posed by the community of co-believers.

The third relevant domain that can present new interesting challenges to the development of Dialogical Self Theory is that of artistic expression. Art is multidimensional dialogical space, including very complex symbolic productions and relationships between the artist Self system and the audience. Very interestingly, psychology has failed to develop a general theory of artistic experience, so far (Tateo, 2016). The role of art in the promotion of social change (Awad \& Wagoner, 2015) and in the development of the personal life trajectory raises many interesting issues: shall we always consider the Self system as dialogical and polyphonic? In this case, what happens to monological aspects of the Self? Or, is instead more fruitful to look at the process of alternation between dialogical and monological spaces, not just considering the monological aspects as superimposed by the oppressive pressure of the societal dynamics? Monological discourse is always present every time we silence the voice of alterity, not letting the other enter our dialogical space. Of course, it is easier to observe this phenomenon according to the distribution of power within the society. Going back to the field of education, it is easier for a teacher to produce a monological discourse than for a pupil or for a majority group over a minority. Nevertheless, as shown in the case art, as for instance in the context of the graffiti people (Awad \& Wagoner, 2015), a monological discourse, in which the other is radically left out as irreducible to my dialogical space, can also occur as a form of resistance in a situation of marginality. One can use the graffiti as a form of identity expression and appropriation of a public space one is usually excluded from. But one can do this either by aiming at constructing a common dialogical space, or by replacing the former occupant. These are the alternatives between co-habiting and colonizing a dialogical space, which is a very issue in contemporary society.

\section{The ontological fallacy}

Considering the Dialogical Self theory, we should avoid falling into a tendency that has always been present in the history of psychology. Paraphrasing William James (1950), I would call it the psychologist's ontological fallacy. The Dialogical Self is a powerful metaphorical description of a process in which through symbolic action the triadic relationship between the self, the alterity and the society mutually co-generates, co-develop through differentiation and mutual recognition. In this sense, monologicality is not the refusal of alterity rather the lack of recognition. On the other hand, psychology often deals with non-existing objects (Valsiner, 2014), such as mind, culture, intelligence, identity, self system, personality traits to mention but few. It is often neglected that these constructs are theoretical elaborations build to understand processes, but soon or later they become things through the symbolic artifacts that the discipline develops to measure and talk about them (Tateo, 2013). When a process is reified into a thing, loses is attributes of dynamicity and multidimensionality. A thing instead acquires properties, parts and features that can be measured, it also acquires causality relationships, things do things. Reification is basically a conceptual and linguistic 
operation of abstraction that transforms processes into their outcomes (Tateo, 2015). Thus, when culture as conceptual tool to understand a process becomes an non-existing object, it acquires the capability to cause some outcomes and can be than used to explain phenomena, like in the case of cross-cultural psychology, in which culture becomes a variable to explain individual variability. The same can be observed with concepts like personality. Once we reify it, distinguishing it in parts, the personality traits that can be measured as stable entities, then personality can be used to explain further phenomena or behaviors. Besides, as the $17^{\text {th }}$ Century philosopher Giambattista Vico, one of the ancestors of cultural psychology, claimed, it is fundamental to look at the historical and concrete conditions in which psychological processes take place, but also to the consideration of the whole, from its genesis to its transformation in something different (Tateo, 2015). The process of reification swipes off the historical dimension of psychological processes. If one considers intelligence, for instance, as a thing that can be measured, it loses any genetic dimension, as well as the fact that cognition, affection and action are always parts of a whole, and they are an action upon the situation. Probably few scholars such as Vygotsky, Piaget and Lewin understood to what extent experiencing is always changing, because the relationship between mind, alterity and culture is co-generative.

I see a similar risk with some applications of Dialogical Self theory, that is to become a modern version of the ancient theme of Psychomachia (battle of spirits), which is present from the very origins of Christian and Islamic traditions (Figure 1) and is still a very popular trope also in contemporary cultural products.

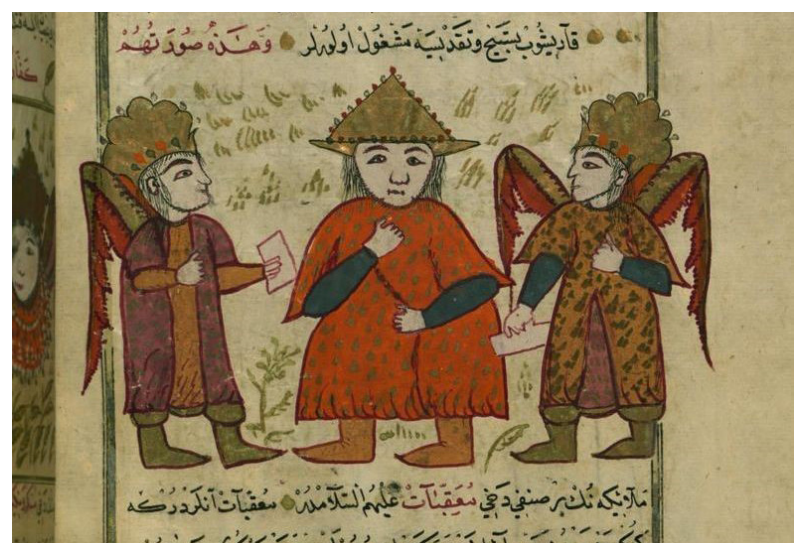

Figure 1. Two Angels, with a Man in the Middle Charged to Write Down his Good and Bad Deeds, (author Zakariya ibn Muhammad Qazwini, 1717 a. C.), Creative Common Licence, Walter Museum 2014

The threat is to transform a process - the polyphonic and dynamic symbolic internalization and externalization through which the person is organizing the relationship with the others and the cultural context - into a thing, a reification of the different I-positions into stable entities inside the mind that can be mapped and measured with the right apparatus. The concrete risk is to transform an active process of elaboration, with his history and situated-ness, into small people inside the mind, like in the trope of bad angel and good angel. On the other hand, the presence of this trope in several historical contexts and literary products was used by Bakhtin as a powerful theoretical tool to study the processes of authorship. The same problem is posed in the reification of the alterity. As in the case of global migrations, one can start by defining alterity as a thing, a stable property of the individual - e.g. the stranger, the Muslim, etc. - and then using it to explain individual behaviors by the essence of being Alter.

This raises another question that is mentioned also by Simão and Sánchez in their article. If Dialogical Self is the abstract description of a process, rather than a structural organization of I-positions, how do we deal with the problem of subjectivity and agency? In other words, how can be a process responsible for the actions, thoughts and feelings that we naturally attribute to a person?

\section{The psychological imagination}

A way of looking at the relationship between subjectivity and multivocality is again that of considering subjectivity not as a thing but as a process. I will here discuss the point of view that psychological processes are fundamentally egocentric and ethnocentric. I shall go back again to Vico's philosophy. He stated that the origin of any experience is the embodied experience of the world (Tateo, 2015). We cannot escape the primary perspective from which we see the world which is the self-centered gaze from the inside to the outside (Benson, 2000) and into an irreversible directionality of life time. This is the fundamentally egocentric perspective from which both the sense of self and of alterity originates. At the same time, our perspective cannot be but ethnocentric, in the sense that we experience the world through the mediation of culture. The problem of the relationship between identity and alterity must start from the point that the Self is an ethnocentric process (Boesch, 1991). This also implies a relativization and a decentralization of the psychological sciences' perspective. "Psychologists, as well as social scientists, should indeed think well before finishing any sentences the subject of which is 'man"'. (Wright Mills, 1959, p. 163). The greatest danger for psychology is indeed to talk about dialogicality from a monological point of view.

Three Centuries ago, Vico already warned us to reflect upon the ethnocentrism of every form of knowledge, looking in a different way to the process of generalization of psychological knowledge (Tateo, 2015). "What social science is properly about is the human variety, which consists of all the social worlds in which men have lived, are living, and might live". (Wright Mills, 1959, p. 132). The articles of this special issue stress a particular focus on development and perspective dimensions of the Self system. They grasp the dialogical space as a place for potential 
development rather than a structured organization of static positions. This is what the psychological imagination can help as the faculty of linking past, present and future in the process of understanding. But this cannot be done without focusing on complex phenomena and processes:

We cannot deduce pedagogics, aesthetics and practical ethics from psychology- But we can observe the spontaneous development of the art of education, of aesthetic production and of ethical life, and the ideals and points of view which are revealed in this development may be understood by the help of general psychological laws. (Höffding, 1905, p. 76)

This implies, in my understanding, that the possibilities of development for the Dialogical Self Theory consist in the focus on developmental and future oriented processes of the Self system. It means that the imaginative processes and the creative aspect must be always carefully considered (Tateo, 2016).

\section{Imaginação psicológica}

Resumo: O comentário apresenta uma reflexão epistemológica sobre a teoria do Self Dialógico. Inicialmente, são discutidas questões teóricas da TSD sobre a relação entre individualidade, alteridade e sociedade, elaboradas com base nos artigos que constam desse número especial. Em seguida, discute-se o argumento da falácia ontológica, ou seja, a atitude de se desviar do estudo do processo para estudar entidades psicológicas. Por fim, propõe-se o desenvolvimento em direção a novas possibilidades de pesquisa, com foco no estudo das funções e dos processos psicológicos superiores, levando em consideração os produtos simbólicos complexos da atividade humana e a imaginação psicológica em desenvolvimento.

Palavras-chave: funções psicológicas superiores, falácia ontológica da psicologia, self dialógico, imaginação psicológica.

\section{L'imagination psychologique}

Résumé: Le commentaire présente une réflexion épistémologique sur la Théorie du Soi Dialogique. Tout d'abord, ils sont abordées les questions théoriques de la DS sur la relation entre l'individualité, l'altérité et la société, en élaborant sur les articles dans ce numéro spécial. Ensuite, on présente l'argument de le sophisme ontologique des psychologues, à savoir la passage de l'étude des processus à l'étude des entités psychologiques. On propose enfin un développement vers des nouvelles directions de recherche, en se concentrant sur l'étude des fonctions et des processus psychologiques supérieurs, tout en tenant compte des produits symboliques complexes de l'activité humaine et le développement de l'imagination psychologique.

Mots-clés: fonctions psychologiques supérieures, erreur ontologique du psychologue, Dialogical Self, imagination psychologique.

\section{La imaginación psicológica}

Resumen: Este texto presenta una reflexión epistemológica sobre la teoría del Self Dialógico. En primer lugar, se discuten las cuestiones de esta teoría sobre la relación entre individualidad, alteridad y sociedad, desarrollando las ideas articuladas en los artículos en este número especial. A continuación, se presenta el argumento de la falacia ontológica de los psicólogos, que es la actitud de pasar del estudio de los procesos al estudio de las entidades psicológicas. Finalmente se propone un desarrollo de nuevas formas de investigación, centrándose en el estudio de las funciones y los procesos psicológicos superiores, teniendo en cuenta los productos simbólicos complejos de la actividad humana y el desarrollo de la imaginación psicológica.

Palabras clave: funciones psicológicas superiores, falacia ontológica del psicólogo, Self Dialógico, imaginación psicológica.

\section{Referências}

Awad, S. H., \& Wagoner, B. (2015). Agency and creativity in the midst of social change. In C. Gruber, M. Clark, S. H. Klempe \& J. Valsiner (Eds.), Constraints of Agency (pp. 229-243). New York, NY: Springer International Publishing.
Benson, C. (2000). The cultural psychology of self: place, morality and art in human worlds. Philadelphia, PA: Routledge.

Boesch, E. (1991). Symbolic action theory and cultural psychology. Berlin, Alemanha: Springer-Verlag. 
Hermans, H.J.M.(2001). The dialogical self: toward a theory of personal and cultural positioning. Culture \& Psychology, 7(3), 243-281. doi:10.1177/1354067X0173001

Hermans, H. J. M. (2014). Self as a society of I-positions: a dialogical approach to counseling. Journal of Humanistic Psychology, 53, 134-159.

Höffding, H. (1905). The present state of psychology and its relations to the neighboring sciences. The Psychological Review, 12(2-3), 67-77.

James, W. (1950). The principles of psychology (Vol. 1 and 2). New York, NY: Dover. (Original work published in 1890)

Simão, L. M. (2012). The other in the self: a triadic unit. In J. Valsiner (Ed.), The Oxford handbook of culture and psychology (pp. 403-420). New York, NY: Oxford University Press..

Tateo, L. (2013). Generalization as creative and reflective act: revisiting Lewin's conflict between Aristotelian and Galileian modes of thought in psychology. Theory \& Psychology, 23(4), 518-536. doi:10.1177/0959354313488844

Tateo, L., \& Marsico, G. (2014). Open complementarity in cultural psychology. In B. Wagoner, N. Chaudhary
\& P. Hviid (Eds.), Culture Psychology and its future: complementarity in a new key (pp. 77-91). Charlotte, NC: Information Age.

Tateo, L. (2015). Giambattista Vico and the principles of cultural psychology: a programmatic retrospective. History of the Human Sciences, 28(1), 44-65.

Tateo, L. (2016). Giambattista Vico and the New Psychological Science. New Brunswick, NJ: Transaction.

Valsiner, J. (2007). Culture in minds and societies: foundations of cultural psychology. New Delhi, India: Sage.

Valsiner, J. (2014). Functional reality of the quasireal: Gegenstandstheorie and cultural psychology today. Culture \& Psychology, 20(3), 285-307. doi:10.1177/1354067X14542532

Wright Mills, C. (1959). The sociological imagination. New York, NY: Oxford University Press.

Received: January 20, 2015

Revised: March 22, 2016

Accepted: April 26, 2016 